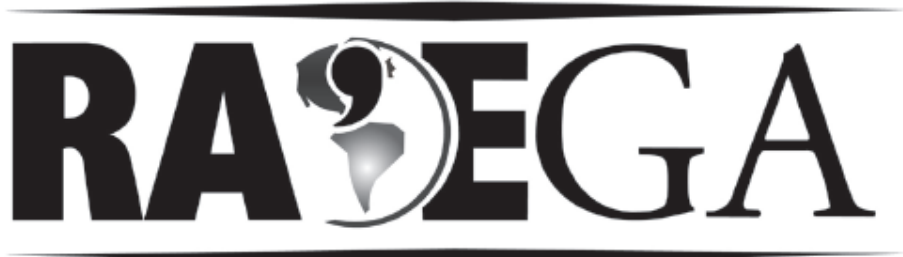

O ESPAÇO GEOGRÁFICO EM ANÁLISE

\title{
Diálogos entre a Geografia Cultural e a Arte-Educação
}

\section{Dialogues between Cultural Geography and Art Education}

\author{
Carlos Weiner Mariano de Souza ${ }^{1}$
}

\section{RESUMO}

A temática deste artigo está centrada na questão da representação do espaço, através da qual buscamos trabalhar dois objetivos centrais. No primeiro deles está a compreensão e análise dos resultados imagéticos produzidos a partir de uma experiência educacional em arte, que se pautou na utilização da linguagem fotográfica, e teve como público-alvo um grupo de moradores da periferia da cidade de Paranaguá, no litoral do Paraná. O segundo objetivo foi destacar as possibilidades da fotografia, enquanto elemento relevante para contribuir na compreensão das leituras do espaço fundamentadas em reflexões advindas da corrente da geografia humanística-cultural. A metodologia de trabalho mesclou a análise de informações empíricas, baseadas nas imagens produzidas pelo grupo pesquisado; bem como a revisão bibliográfica, a partir das obras de Ana Mae Barbosa, Giulio Carlo Argan, Yi-fu Tuan, Serge Moscovici, Jean-François Staszak e Boris Kossoy. Aponta-se como resultado desta análise a vasta possibilidade que a fotografia pode trazer, no sentido de contribuir para a leitura e interpretação do espaço, tanto no aspecto físico, mas em especial nos aspectos da subjetividade humana e da construção social.

Palavras-chave: Arte-educação; Geografia Cultural; representação; percepção; fotografia.

\footnotetext{
${ }^{1}$ Artista visual e Arte-educador. Licenciado em Artes Visuais pela Universidade Federal de Uberlândia, especialista em Música no século XX - Computação Sônica, pela Universidade Federal de Uberlândia, Mestrando em Artes Visuais pela Escola de Comunicação e Artes da Universidade de São Paulo, ECAUSP. End.: Rua Cornélio Procópio, 906. Bairro: Caiobá. Cidade: Matinhos- PR Fones: (41) 3473196588847391 Emails: weiner@usp.br. - caweca@terra.com.br
} 


\title{
ABSTRACT
}

The theme of this article focuses on the question of representation of space, through which we intend to broach two central objectives. The first one is the understanding and analysis of results photographics produced from an art educational experience, which is guided in the use of photography language, and has a target audience group of people on the outskirts of the city of Paranagua, in Parana coast. The second objective was to highlight the possibilities of photography as a major factor contributing to the understanding of the interpretations of the area based on ideas stemming from the current of humanistic and cultural geography. The methodology merge empirical analysis of information, based on photographies produced by the group studied, and the literature review, from Ana Mae Barbosa, Giulio Carlos Argan, Yi-Fu Tuan, Serge Moscovici, Jean-François Staszak and Boris Kossoy theories. Suggestions are made as a result of this review the wide scope that can bring the photo in order to contribute to the reading and interpretation of space, both in physical appearance, but in particular aspects of human subjectivity and social construction.

Keywords: Art Education; Cultural Geography; representation; perception; photography.

\section{Espaço curvo e finito}

\author{
Oculta consciência de não ser, \\ Ou de ser num estar que me transcende, \\ Numa rede de presenças e ausências, \\ Numa fuga para o ponto de partida: \\ Um perto que é tão longe, um longe aqui. \\ Uma ânsia de estar e de temer \\ A semente que de ser se surpreende, \\ As pedras que repetem as cadências \\ Da onda sempre nova e repetida \\ Que neste espaço curvo vem de ti.
}

(José Saramago. In OS POEMAS POSSÍVEIS,

Editorial CAMINHO, Lisboa, 1981. 3ª edição)

Este texto parte da reflexão sobre a representação do espaço, a construção de identidades, e a educação do olhar a partir de imagens fotográficas produzidas por um grupo de moradores da Vila Santa Maria, periferia da cidade de Paranaguá, litoral do Paraná. Tomamos como ponto de partida a linguagem fotográfica buscando perceber como esses atores representam os espaços vividos e como os signos construídos a partir destas experiências são representativos, em seu processo circulatório, em sua 
mobilidade, de uma relação identitária complexa com os diversos espaços da cidade.

Para tanto, fundamentamo-nos no instrumental teórico proporcionado pela arte-educação em diálogo com geografia humanística-cultural e as teorias que tratam da representação, do signo fotográfico, das práticas relacionadas à ação cultural e inclusão social. Destacamos a intencionalidade de buscar o equilíbrio entre as proposições teóricas baseadas na construção social do indivíduo, suas representações e os comportamentos social e culturalmente determinados, e aquelas que entendem a relevância da singularidade e autonomia do sujeito.

A gênese desta experiência se deu a partir de um projeto educacional desenvolvido pela UFPR, setor Litoral ${ }^{2}$, na implementação de um conjunto de ações voltadas para a perspectiva do desenvolvimento humano da comunidade. Através desta, foram desencadeadas ações articuladas, que tinham na percepção estética, nos aspectos socioculturais da cidade, com ênfase no espaço, um eixo objetivo de ação e um eixo subjetivo de pertencimento.

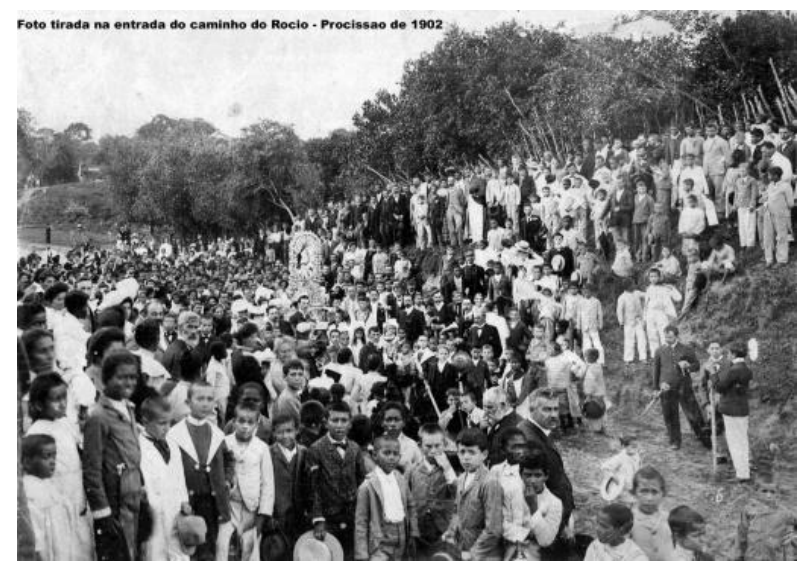

Figura 1 - Foto: Procissão de Nossa Senhora do Rocio, 1902. Autor: Desconhecido. Fonte: Instituto Histórico Geográfico de Paranaguá.

O fio condutor para a realização da experiência educacional foi o olhar fotográfico sobre a cidade e suas formas, seus espaços e suas histórias. Foram

\footnotetext{
${ }^{2}$ A experiência analisada neste artigo é fruto do desenvolvimento de um projeto educacional de cunho sociocultural, protagonizado pelo programa de extensão Incubadora Tecnológica de Cooperativas Populares da UFPR Litoral.
} 
utilizadas as imagens da história da cidade de Paranaguá, como se pode ver na Figura 01, que datam de 1897 à década de 1960, e proporcionado aos participantes a visitação e vivência destes espaços. Da mesma forma, imagens de manifestações populares como desfiles e festas religiosas deram subsídio ao processo. Também tiveram destaque as imagens fotográficas e textos sobre os espaços e monumentos que ilustram o discurso oficial sobre a história e o desenvolvimento da cidade, consagradas através da veiculação organizada pelos órgãos do Estado ${ }^{3}$.

Tendo em vista a do conceito de espaço ${ }^{4}$ no campo teórico da geografia, consideramos a importância de nos debruçarmos preliminarmente sobre seu tratamento no corpo do trabalho. Percebemos aqui o espaço como sendo a categoria contemporânea capaz de fundir os elementos cindidos pela modernidade na análise geográfica. Aparece como resultante do casamento entre sociedade e paisagem. Estes, por sua vez, configuram um par dialético e dialógico na medida em que se complementam e se opõem (SANTOS, 1988, p. 26).

O conceito de espaço é a busca de uma nova síntese no objeto da pesquisa geográfica. Através dele o pesquisador é levado a pensar o mundo a partir da consciência de que o mesmo é representação do humano, é fruto de sua existência. "O espaço é resultado da ação dos homens sobre o próprio espaço, intermediado pelos objetos, naturais e artificiais" (SANTOS, 1988, p. 25). O espaço é também incorporador das marcas temporais da história humana. Neste sentido, recupera as duas categorias essenciais da existência humana, o tempo e o espaço. É da amálgama destes dois elementos que surge o sentido da memória espacial.

Em se tratando da cidade de Paranaguá, receptora da experiência, é importante ressaltar que há uma memória espacial documentalmente consolidada. Os fragmentos desta referem-se tanto ao final do período colonial,

\footnotetext{
${ }^{3}$ As imagens históricas foram obtidas junto ao acervo do Instituto Histórico e Geográfico de Paranaguá (IHGP) e do Instituto de Patrimônio Histórico e Artístico Nacional (IPHAN).

${ }^{4}$ A referência em Milton Santos para discutir o conceito ou mesmo uma noção consistente de espaço tornou-se quase impositiva, ainda que este autor não possa ser inserido no grupo de pensadores que se referenciam na base fenomenológica para pensar o fenômeno geográfico no contexto contemporâneo.
} 
expressos através das pinturas e descrições textuais da cidade, a exemplo das referências de August Saint-Hilaire ${ }^{5}$, quanto do final do século XIX até a primeira metade do século $\mathrm{XX}$, por meio de registros fotográficos. Ambos fazem-se enfaticamente presentes no imaginário da cidade. As imagens fotográficas, por sua vez, são divulgadas tanto por órgãos oficiais do poder público, quanto por particulares que as circulam disponibilizando-as através da mídia eletrônica, internet. Interessante relevar que, a investigação sobre este último aspecto, a representação do espaço no universo virtual, apresenta-se como um campo aberto aos estudos e merece, em outra oportunidade, aprofundamento devido.

Trabalhando a imagem fotográfica em seus aspectos estéticos, técnicos e ideológicos, os caminhos adotados ao longo a experiência se apoiaram na idéia de ação coletiva (cultura), e no exercício da subjetividade em relação à percepção e representação do espaço. Entendendo a relação entre a expressão coletiva e o exercício da subjetividade em seu entrelaçamento dialógico. Importante ressaltar que a caminho adotado, no que se refere ao processo de ensino aprendizagem, teve com ponto de partida o aporte teórico de Ana Mae Barbosa (2009) em seu esforço para refletir a área de ArteEducação em relação com a cultura que nos cerca. A partir daí buscou-se a ênfase no espaço, tornando-o interlocutor do que esta autora classifica como "um contextualismo esclarecedor que amplia a noção de experiência ${ }^{6}$ e lhe dá uma densidade cultural" (BARBOSA, p. 61, 2009).

[...] a educação é mediatizada pelo mundo em que se vive, formatada pela cultura, influenciada por linguagens, impactada por crenças, classificada pela necessidade, afetada por valores moderada pela individualidade. Trata-se de uma experiência com o mundo empírico, com a cultura e a sociedade personalizada pelo processo de gerar significados, pelas leituras pessoais auto-sonorizadas do mundo fenomênico e das "paisagens interiores". BARBOSA, p.62, 2009).

\footnotetext{
${ }^{5}$ Viajante-naturalista, em visita ao sul do Brasil ainda na primeira metade do século XIX.

${ }^{6}$ Referimo-nos ao conceito de Arte como experiência elaborado por John Dewey em 1934.
} 
A cidade aparece como um elemento norteador, na busca de significados e de elaboração/reelaboração da vivência neste espaço heterogêneo. Identidade, memória e valor em relação à cidade são elementos subjacentes e subjetivos com os quais trabalhamos ao longo da experiência. Argan (1995, p. 231) ratifica as possibilidades que se abrem na perspectiva do indivíduo-sujeito em sua relação profunda com a cidade. A partir da percepção tornam-se incontáveis as formas e valores simbólicos que podem fluir do contato visual do habitante com a cidade.

De acordo com Benévolo (1991, p. 13) um dos sentidos da cidade é configurar a representação da situação física da sociedade. As características do espaço que se conformam no organismo da cidade tendem a subverter 0 tempo e persistir, em geral mais que a própria forma de organização da sociedade.

A cidade representa um conjunto de artefatos artificiais, introduzidos pelo homem em uma porção do ambiente natural. Constitui também a expressão cultural de uma organização social, uma organização de experiências (BENÉVOLO, 1991).

A história da cidade moderna, oriunda do Velho Mundo, teve ressonância muito grande nos países que se organizaram e/ou transitaram forçosamente rumo à modernidade. As cidades deste 'novo' mundo consistem em fruto da herança de dominação, tiveram os rumos de sua história alterados em função das características específicas de sua inserção no capitalismo. De tal forma, que sua expressão territorial combina um mosaico de elementos culturais.

Há um caráter de mosaico que caracteriza o espaço de Paranaguá. Suas contradições, suas marcas do tempo estão expressas nas ruelas, nos monumentos, no conjunto do patrimônio material, bem como em sua extensa periferia em contraponto a aparência tecnológica expressa pelo moderno mobiliário portuário. Exatamente por isso, o próprio espaço da cidade tornou-se ofertante de um conjunto muito variado de possibilidades para pesquisa. 
O processo de realização da experiência contou com visitações fotográficas, a vivência dos espaços, exercícios e discussões temáticas sobre a cidade. O caráter lúdico e de lazer, combinado à estimulação da curiosidade e instigador do desejo de conhecer provocaram os participantes no sentido de indagar a existência e a importância de cada um daqueles espaços, em princípio distantes de sua realidade, em vários sentidos.

"A Geografia humanista-cultural privilegia novas qualidades como subjetividade, intuição, sentimentos, experiências e simbolismos" (KOZEL, 2007, p.118). Afasta-se de uma leitura lógico positivista do espaço e filia-se às orientações teóricas da fenomenologia e do existencialismo, que percebem os indivíduos como agentes agregadores de pluralidade e complexidade ao espaço. O espaço passa a ser entendido como "espaço vivido pelas experiências humanas, cada ser humano em sua individualidade. Por isso, ressignificam categorias como a "paisagem" e o "lugar" que passa a fazer parte dos debates sobre a objetividade e a subjetividade na geografia" (TUAN 1983 apud KOZEL 2007).

A Vila Santa Maria, local de onde provêm todos os participantes da experiência proposta, representa, como em geral as regiões periféricas das cidades brasileiras, a expressão espacial das contradições do capitalismo concentrado e concentrador. Trata-se de uma área conexa ao Lixão do município e que possui duas formas sobrepostas de ocupação territorial ${ }^{7}$. Originalmente, esta área era configurada por chácaras tradicionais, cuja ocupação se deu nos anos 1950. A partir da década de 1970, a expansão urbana começou a exercer interferências na dinâmica deste lugar em função da deposição de lixo. A instalação industrial foi um segundo fator importante que gerou alterações neste espaço, sobretudo nos anos 1990. Parte do espaço passou a ser ocupado por indústrias e parte pelo Lixão, que se deslocou, mas permaneceu na região.

\footnotetext{
${ }^{7}$ As informações histórico-espaciais da Vila Santa Maria foram extraídas do relatório Diagnóstico socioeconômico da Vila Santa Maria, produzido em 2008.
} 


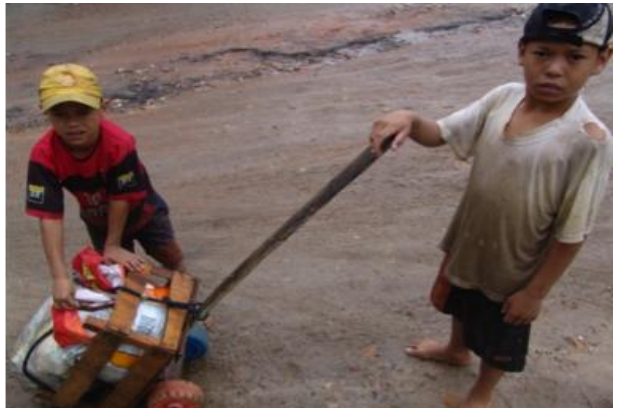

Figura 02. Foto: Crianças brincam imitando a atividade dos pais. Fonte: acervo do autor. Autor: Carlos Weiner.

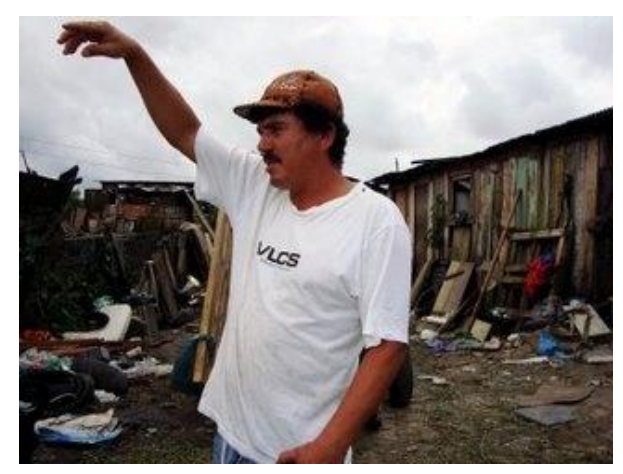

Figura 04. Foto: Residências na Vila. Fonte: Projeto Vila. Autor: Alessandra Dias (13 anos).

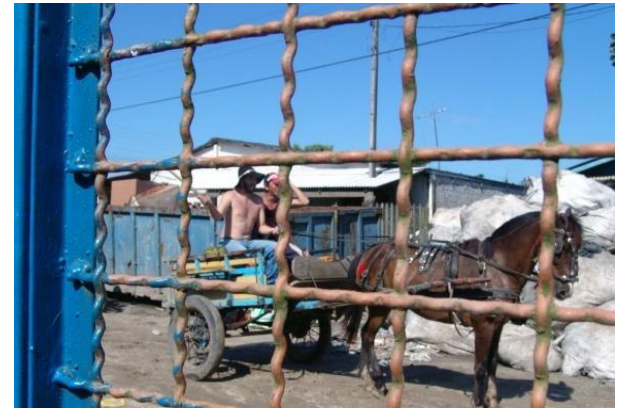

Figura 03. Foto: Corrida de Carroças na Vila Santa Maria. Fonte: acervo do autor. Autor: Carlos Weiner.

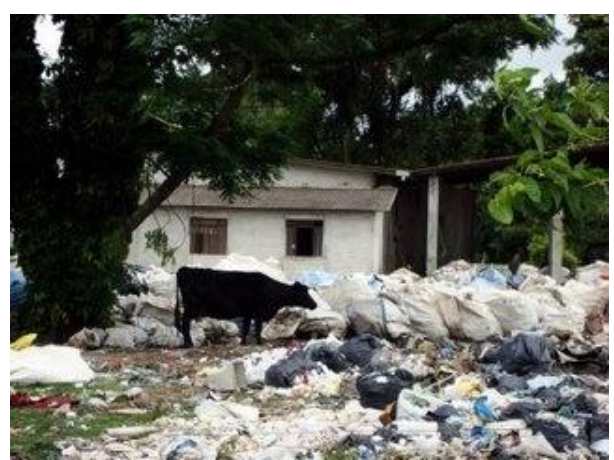

Figura 05. Foto: Residências na Vila Fonte: Projeto Vila. Autor: Cristofer Luiz (14 anos).

A ocupação industrial gerou uma realocação das famílias que ocupavam originariamente o espaço, o que foi agregado pelo processo migratório tipicamente urbano, gerado pela atratividade exercida pelo Lixão. Passaram, então, a coexistir antigos chacareiros, que preservam ainda hoje área de agricultura em lotes agora bastante reduzidos, e famílias que trabalham na catação do lixo. A pressão destes dois fatores gerou um processo de degradação ambiental e social bastante profundo, que se combina a uma relação clientelista muito forte com o poder público (ITCP, 2008). No zoneamento da cidade não consta a delimitação da Vila. Na verdade, o próprio nome é fruto da organização informal de uma das diversas áreas de ocupação / invasão no município. Oficialmente, esta área compõe a Colônia Santa Rita, constituída na zona rural e que em função da expansão portuária das últimas décadas já adentrou o espaço urbano. O mapa acima reflete as características deste espaço, situado próximo à estrutura da Indústria de Alimentos Sadia e do 
Lixão municipal. Tanto a Sadia, enquanto empresa relevante para o município, como o Lixão de Paranaguá constituem elementos de elevado impacto sobre a vida dos moradores ali instalados.
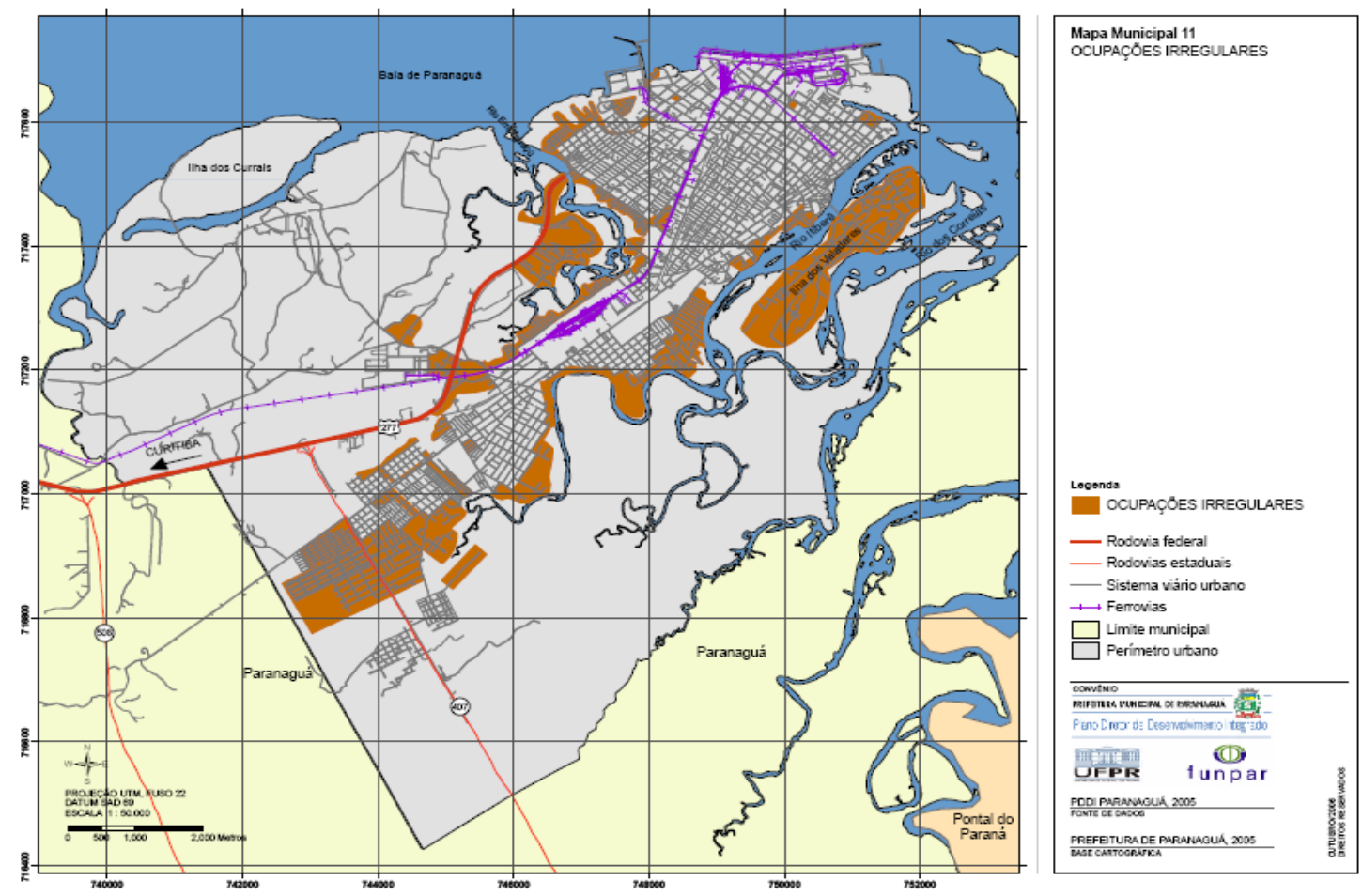

Figura 06: Mapa de Ocupações Irregulares. Fonte: Plano Diretor da Cidade de Paranaguá.

Atualmente, cerca de 1200 pessoas residem no local, sendo que a maior parte delas obtém seu sustento da atividade de coleta, separação e venda do lixo reciclável. O modo de vida estruturado neste ambiente reproduz a segregação ao longo do tempo, passando a desesperança e a lógica da sobrevivência a imperar no cotidiano da população adulta e jovem.

As imagens 02 e 03 destacam algumas das formas de lazer das crianças e dos adultos na Vila. Os adultos costumam organizar corridas de carroças na rua principal, enquanto as crianças brincam produzindo carrinhos que imitam a atividade profissional dos adultos.

A multiplicidade na utilização do espaço fica evidente nas imagens $04 \mathrm{e}$ 05. O mesmo espaço, além de ser utilizado como moradia e depósito de materiais (lixo), que passarão por seleção antes de serem comercializados, 
comporta a criação de animais, tanto de trabalho como para consumo (ITCP, 2008). Não há uma demarcação lógica da funcionalidade do espaço, separando os lugares para a prática do lazer, do trabalho e da moradia.

Algumas destas práticas têm seus rebatimentos na forma como o lugar, Vila Santa Maria, é percebido e referenciado pelo conjunto da cidade ${ }^{8}$. Uma área de ocupação, depósito de lixo, estigmatizada em função da pobreza econômica de seus moradores. O que objetivamente nos remete ao conceito de Representação Social, forjado por Serge Moscovici (2000), no qual a legitimação de conhecimento pela atividade intelectual é compartilhada socialmente no cotidiano. Neste sentido, menos compromissada com as exigências da objetividade, como no caso da ciência e do universo reificado, e mais ligada à verossimilhança, ao senso comum, que constrói o medo e o preconceito pela diferença em relação ao lugar e às pessoas.

\begin{abstract}
Las representaciones sociales son entidades casi tangibles. Circulan, se cruzan y se cristalizan sin cesar en nuestro universo cotidiano a través de una palabra, un gesto, un encuentro. La mayor parte de las relaciones sociales estrechas, de los objetos producidos 0 consumidos, de las comunicaciones intercambiadas están impregnadas de ellas. Sabemos que corresponden, por una parte, a la sustancia simbólica que entra en su elaboración y, por otra, a la práctica que produce dicha sustancia, así como la ciencia o los mitos corresponden a una práctica científica y mítica. (MOSCOVICI, 2002)
\end{abstract}

Agregamos também dois conceitos que se contrapõem e se complementam, tratados por Yi-Fu Tuan $(1980,2006)$, topofilia e topofobia. Se por um lado existe um sentimento comum de medo por espaços - topofobia com as características da Vila Santa Maria; por outro, manifestou-se pela representação fotográfica uma relação afetiva e prazerosa, de pertencimento ao lugar - topofilia - por parte de seus moradores. Yi-Fu Tuan traz o foco central das leituras de mundo na perspectiva do espaço enquanto "espaçovivido", questiona o que é o espaço e o lugar em termos de experiência humana. Para Tuan (1983, p.18), "os espaços do homem refletem a qualidade

\footnotetext{
${ }^{8}$ É bastante comum ouvir da população da cidade de Paranaguá a referência à Villa Santa Maria e aos seus habitantes pelas expressões "Lixão, pessoas do lixão".
} 
dos seus sentidos e sua mentalidade". Desta feita, consolida a idéia de que o espaço reside não apenas fora, mas também dentro do ser humano ${ }^{9}$.

A imagem fotográfica é o adensamento destas intencionalidades, é a representação do espaço a partir de uma realidade corpórea.

O processo de construção do signo fotográfico implica necessariamente a criação documental de uma realidade concreta. A representação fotográfica é uma recriação do mundo físico ou imaginado, tangível ou intangível; o assunto registrado é produto de um elaborado processo de criação por parte de seu autor. O fotógrafo constrói o signo, a representação (kossoy, 2002, p. 42).

O senso comum tem fortemente a fotografia associada a uma idéia de realidade, fundamentalmente porque somos em parte atores e autores da experiência, tanto como capturadores das imagens, como capturados nelas. Kossoy (2002, p.137) desconstrói essa leitura primeiramente afirmando que 0 passado é o lugar de toda fotografia, e se o passado é momento vivido ele é irreversível. Todas as intencionalidades, sensações, impressões, emoções e que vivemos naquele instante são registradas em nossas intimidades em forma de impressões.

A fotografia, obviamente, não guarda essas impressões - elas situam-se ao nível do invisível, além da imagem. São emoções que não podem ser gravadas materialmente: residem em nosso ser e só a nós pertencem. São emoções que não apenas sentimos, mas que também imaginamos, sonhamos e, portanto, vemos (KOSSOY, 2002. p.137).

Neste sentido, a aparência visível da fotografia é um fragmento do mundo da vida que se pretendeu apresentar, uma tentativa de preservar o passado, o instante vivido, uma representação que passa pelos filtros culturais e afetivos do sujeito. Um signo, que ao ser colocado à disposição da percepção do sujeito desencadeará os processos de resignificação do mundo. Mesmo que a princípio a realidade da imagem fotográfica aparente ser a do recorte visível de uma realidade material, o que se nos apresenta é outra realidade, a do

\footnotetext{
${ }^{9}$ Esta mesma relação de topofilia e topofobia se reproduz na escala do bairro. No processo de visitação fotográfica, alguns dos participantes do projeto expressaram desconforto em percorrer determinadas partes da vila. O processo de segregação espacial expresso pelos depoimentos se ancoravam em argumentos que explicitavam desde a forma de construção das habitações, até a da pavimentação das vias, como forma de diferenciação social. A expressão "o povo do fundo" foi utilizada várias vezes por crianças que se referiam a outras, cujas casas estavam localizadas em ruas sem pavimentação e mais próximas ao lixão.
} 
documento que instiga os sentimentos, que evoca nossa relação com o espaço, o tempo, com o outro e com nós mesmos.

A produção fotográfica oriunda do trabalho com o grupo da Vila Santa Maria gerou dois grupos de imagens. Um derivado da percepção e interrelação oferecida pelas paisagens, pela vivência dos conjuntos arquitetônicos históricos, praças, vias públicas da cidade, e outro das relações que as pessoas têm com o espaço onde residem.

A análise dos dois grupos de imagens produzidas permitiu identificar relações distintas. Quando colocadas em diálogo as imagens revelam, tanto aspectos sobre o caráter de pertencimento ou não, de identidade ou não com o lugar, como uma relação mais formal, de afastamento.

A ênfase aos aspectos formais, a captação criativa dos ângulos e da perspectiva, a busca do elemento cromático e seus diálogos com as estruturas da arquitetura, têm maior destaque nas imagens produzidas na região central da cidade. Enquanto na vila preponderam os elementos biográficos da comunidade. $O$ elemento humano tem destaque através dos retratos ou da sua relação com os espaços de convivência. As Figuras 07, 08, 09 e 10 configuram esta distinção.

É fundamental destacar que o espaço nos dois conjuntos de imagens é afetivo, edificante. Reflete o elemento de identidade homem-espaço, o espaço em sua faceta concreta, aquela que se traduz na paisagem humana. Segundo Kozel (2007, p. 120), "a apreensão do espaço relaciona-se às diferentes perspectivas que se fazem presentes na visão de cada ser humano. As experiências que os seres humanos têm com os elementos do espaço se constituem diferencial no momento de sua representação".

A imagem fotográfica é criada por inteiro, de um único golpe. Um corte sobre o fio da duração e no continuum da extensão. Temporalmente a imagem ato fotográfico interrompe, detém, fixa, imobiliza...desprende da duração captando um só instante. Espacialmente, da mesma maneira, fraciona, elege, isola...uma porção da extensão (DUBOIS, 1986, p.141). 
A preponderância de certos aspectos em um conjunto de imagens, ou outro, não indica uma contraposição, mas a complementaridade e a pluralidade. Não há que se fazer a comparação qualitativa entre as imagens, o que constituiria um enorme equívoco. Buscamos sim compreender suas intencionalidades, inclusive pelo que nelas está ausente. O que é oferecido à

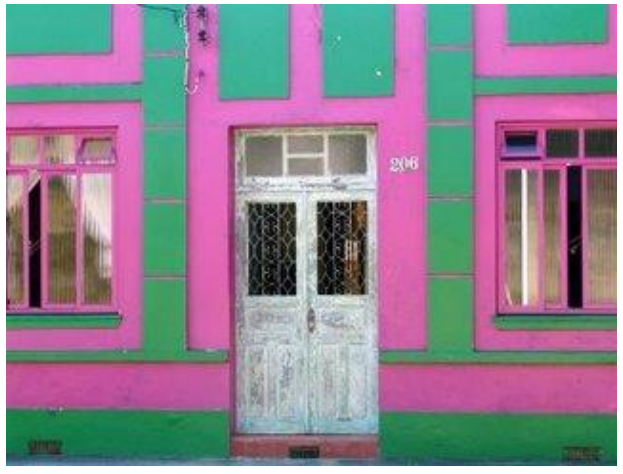

Figura 07. Foto: Fachada. Fonte: Projeto Vila. Autor: Douglas Silva, (13 anos).

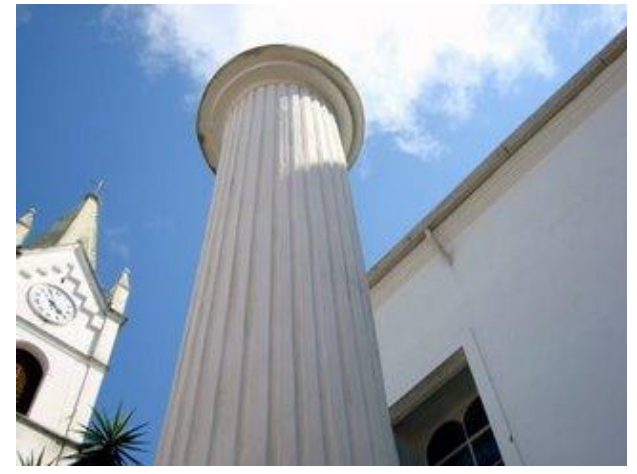

Figura 08. Foto Igreja Matriz Fonte: Projeto Vila. Autor: Camila Alves, (13 anos).

nossa percepção é oferecido por alguém, através de um documento, o fotográfico, inserido em um contexto histórico, geográfico e provocador dos nossos mecanismos de interpretação do mundo, do exercício da subjetividade.

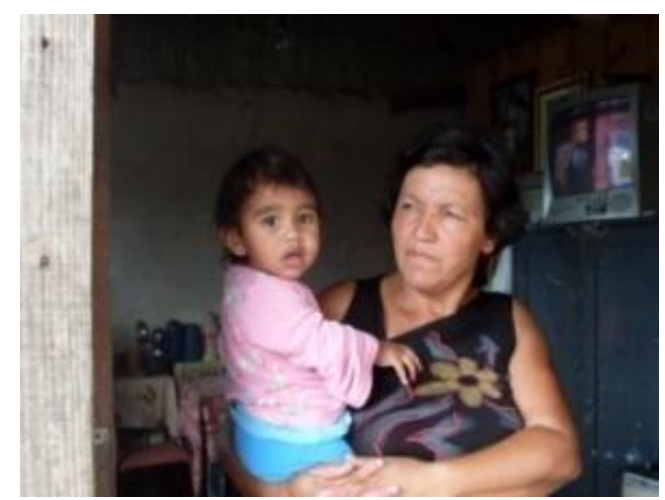

Figura 09. Foto: Moradores da Vila. Fonte: Projeto Vila. Autor: Cristofer Luiz, (15 anos).

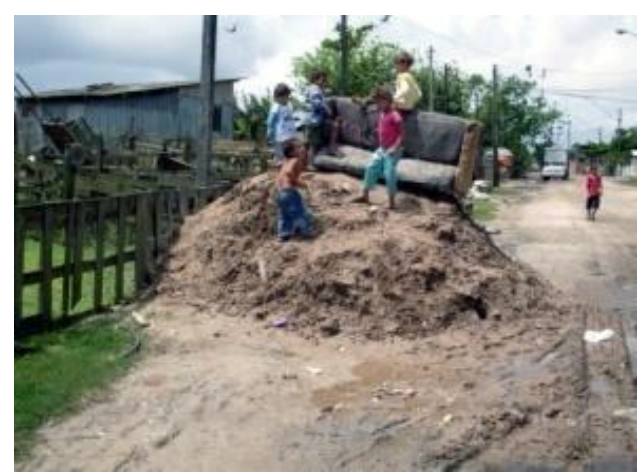

Figura 10. Foto: Crianças brincando. Fonte: Projeto Vila. Autor: Alessandra Dias, (14 anos).

Em sua experiência diária, o sujeito conhece e se reconhece no lugar onde vive. Percebe a casa que habita e a rua em que anda. Faz escolhas espaciais, e pela sensibilidade e interesse dá sentido e valor aos espaços, aos lugares.

O contato com os monumentos e espaços que fazem parte da história oficial da cidade de Paranaguá, cuja fundação provém do século XVII, igrejas, 
museus, prédios da administração pública evidenciou o distanciamento que as pessoas da Vila Santa Maria têm com estes signos da cidade. Mesmo as ruínas da cidade, Paranaguá tem muitas em função do descaso com 0 patrimônio histórico, não despertou, a princípio, interesse relevante. Segundo Sahr (2007, p.62), "a estrutura de um bairro pode ser diferenciada conforme os seus aspectos funcionais, valorativos e socioculturais, mas também por meio de aspectos do mundo vivido dos seus moradores, ou valores estéticos e artísticos".

É o confronto entre a realidade que se vê: a segunda realidade (a que se inscreve no documento, a representação) - através de nossos filtros culturais, estético-ideológicos - e a realidade que se imagina: a primeira realidade (a do fato passado), recuperado apenas de maneira fragmentária por referências (pleno de hiatos) ou pelas lembranças pessoais (emocionais). Há, pois, um conflito constante entre o visível e o invisível, entre o aparente e o oculto. Há enfim uma tensão perpétua que se estabelece no espírito do receptor quando diante da imagem fotográfica em função de suas imagens mentais.

A realidade passada é fixada, imutável, irreversível; se refere à realidade do assunto no seu contexto espacial e temporal, assim como à da produção da representação. É este o contexto da vida: primeira realidade. A fotografia, isto é, o registro criativo daquele assunto, corresponde à segunda realidade, a do documento. A realidade nele registrada é fixa e imutável, porém sujeita à múltiplas interpretações (KOSSOY, 2002, p.47).

Os objetos do passado, a noção de patrimônio, os signos da cultura não são comuns a todos os indivíduos, grupos ou classes sociais. Na diversidade, tornam-se significativos e têm mais ou menos relevância para construção da identidade cultural dos sujeitos. No entanto, o processo educacional e de aprendizagem, que conduz à vivência com estes signos e decifra os códigos que Ihes dão acesso, pode romper as barreiras que impedem não a significação diversa, que é imprescindível para mobilidade social, mas a inacessibilidade que sustenta a exclusão.

O processo desencadeado pela ação de fotografar, os exercícios de educação do olhar e refinamento da sensibilidade, a vivência dos espaços, bem como a reflexão e discussão sobre estes processos, possibilitaram a percepção da cidade a partir de outra perspectiva que não a utilitarista e 
funcionalista. Este procedimento, além de diminuir a distância entre os participantes da experiência e os conjuntos que compõem a cidade, fortaleceu

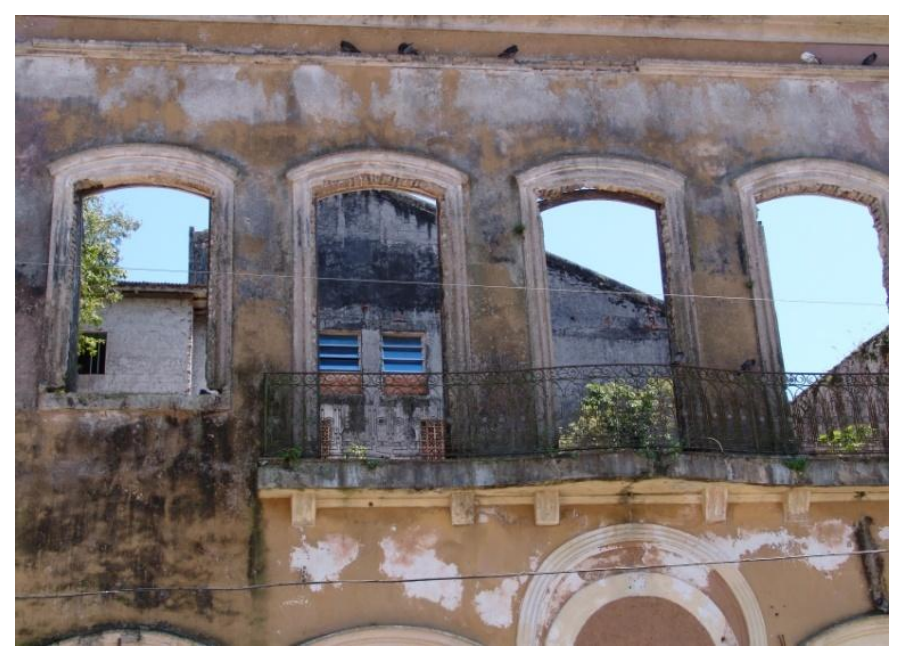

Figura 11: Fachada do Centro Histórico. Fonte: Projeto Vila. Autor: Leonardo Silva (14 anos).

os laços afetivos, a auto-estima e criou novos significados sobre o próprio espaço da Vila.

Tuan (1980 p. 240, 247) aponta para o elo afetivo entre o espaço e o sujeito, e dos vários sujeitos que comungam do espaço. Desta relação emergem valores, diferenças entre a leitura de quem vive e quem visita um determinado lugar. Afirma que viagens para fora, para o mundo exterior, podem ampliar a percepção e reforçar a identidade em relação ao próprio lugar onde se vive.

As imagens produzidas no contexto da Vila Santa Maria evidenciam o sentimento de pertencimento e identidade com o lugar. Mas, uma identidade particularizada pela expressão de cada indivíduo, uma relação inter subjetiva_ entre sujeitos da experiência_que agregada aos seus pares parece configurar uma expressão coletiva. A circulação destas imagens, a partir de sua exposição, na Vila e nos espaços de apreciação nas cidades de Paranaguá e 
Curitiba $^{10}$, ofereceram a possibilidade de uma outra forma de perceber as relações entre os espaços periféricos e o centro da cidade.

Outro elemento emerge desta dinâmica, o processo desencadeado nos receptores, não apenas no que se refere às suas particularidades estéticas, em suas intencionalidades comunicativas, mas com o que estas imagens podem provocar nos processos de releitura do espaço. Desta forma, possibilitando sua contínua reconstrução e a configuração daquilo que JeanFrançois Staszak (2003) denomina como uma geografia dos mundos interiores, do imaginário. Uma geografia que se move com a subjetividade, é transportada pelo indivíduo na relação com a representação, com o signo, e que aflora no contato o documento proporcionado pela arte, em especial pela fotografia.

... do ponto de vista do receptor, há um confronto entre o documento presente (originado no passado) com o próprio passado intangível fisicamente, apenas mentalmente, subjetivamente. (KOSSOY, 2002, p. 46,47$)$.

Podemos dizer que a partir desta experiência que se pautou na linguagem fotográfica, em um contexto que interconecta o sujeito com diversos espaços da sociedade, a partir de uma perspectiva educativa, trouxe uma diversidade de elementos para reflexão. Em especial no diálogo do campo da arte-educação com o geográfico, permitiu que pudéssemos compreender parte importante dos resultados e dos processos que decorreram da implementação da proposta.

Além disso, explicitou novos elementos, tais como a relação entre 0 documento proporcionado pela arte, em particular o fotográfico, e as formas de percepção e representação do espaço, vistos a partir de sua relação com os mecanismos de construção da interpretação por parte dos receptoresinterlocutores. Da mesma maneira contribuiu sobremaneira nos processos de contextualização necessários ao campo da arte-educação. Sendo assim, vão

\footnotetext{
${ }^{10}$ As imagens produzidas na experiência foram expostas na Caixa Econômica Federal, no projeto "Museu Itinerante" no saguão do prédio histórico da Universidade Federal do Paraná e no Jardim Botânico da Cidade de Curitiba.
} 
se desnudando uma multiplicidade de campos do conhecimento que se encontram pouco explorados em suas possibilidades de aproximação.

\begin{abstract}
Encontrar um território é também encontrar uma distância. A minha distância em relação ao outro comporta uma ética. A distância que é preciso demarcar, não avançar, a justa distância que permite o comum. A experiência estética é uma experiência no mundo comum (LIMA, 2006, p.4).
\end{abstract}

\title{
REFERÊNCIAS
}

ARGAN, Giulio Carlo. História da Arte Como História da Cidade. São Paulo: Martins Fontes, 1995.

BARBOSA, Ana Mae. A imagem no Ensino da Arte. São Paulo: Ed. Perspectiva, 2007.

Arte-Educação Contemporânea ou Culturalista. In: RIBEIRO, José Mauro Barbosa (Org.). Trajetória e políticas para o ensino das artes no Brasil: anais do XV Confaeb. Edições MEC-Unesco. Brasília, 2009.

BENÉVOLO, Leonardo. A cidade e o arquiteto. Trad. Attílio Cancian. São Paulo: Ed. Perspectiva, 1991.

DUBOIS, Phillipe. EI Acto Fotográfico; de la Reprensentación a la Recepición. Barcelona: Paidós, 1986. Incubadora Tecnológica de Cooperativas Populares. ITCP - UFPR Litoral. Diagnóstico Sócio Econômico da Vila Santa Maria. Matinhos, UFPR Litoral, 2008.

KOSSOY, Boris. Realidades e Ficções na Trama Fotográfica. São Paulo: Ateliê Editora, 2002.

KOZEL, Salete. Mapas Mentais - Uma Forma de Linguagem: Perspectivas Metodológicas. IN: KOZEL, Salete; SILVA, Josué da Costa; GIL FILHO, Sylvio Fausto.(Orgs). Da percepção e Cognição à representação: Reconstruções Teóricas da Geografia Cultural e Humanista. São Paulo: Terceira Margem; Curitiba: NEER, 2007.

LIMA, Elizabeth. Acerca das cartografias cidadianas de lucimarbello da Vila Olímpia, 2006. Disponível em: <http://www.lucimarbello.com.br>. Acessado em : maio de 2009.

SÁ, Celso Pereira de. A Construção do Objeto de Pesquisa em Representações Sociais, Rio de Janeiro: EdUERJ,1998. 
SAHR, Wolf-Dietrich. Signos e Espaço Mundos - A Semiótica da Espacialização na Geografia Cultural. IN: KOZEL, Salete; SILVA, Josué da Costa.; GIL FILHO, Sylvio Fausto.(Orgs). Da percepção e Cognição à representação: Reconstruções Teóricas da Geografia Cultural e Humanista. São Paulo: Terceira Margem; Curitiba: NEER, 2007.

SANTOS, Milton. METAMORFOSES DO ESPAÇO HABITADO Fundamentos Teórico e metodológico da geografia. São Paulo: Hucitec, 1988.

STASZAK Jean-François, Géographies de Gauguin. Genebra: Editora Editions Bréal, 2003.

MOSCOVICI, Serge. La Representación Social: Um Concepto Perdido. In: IEP - Instituto de Estudios Peruanos Taller Interactivo: Prácticas y Representaciones de la Nación, Estado y Ciudadanía en el Perú Lima,2002.

TUAN, Yi-Fu. Topofilia: um estudo da percepção, atitudes e valores do meio ambiente. São Paulo: Difel, 1980.

TUAN, Yi-Fu. Paisagens do medo. São Paulo: Unesp, 2006. 